\title{
東洋医学と西洋医学の融合
}

一 口腔・咽喉頭分野より一

守

\section{Combination Therapy with Kampo and Modern Medicines in the Oral Cavity and Pharyngo-Laryngeal Diseases}

\author{
Mamoru Tsukuda \\ (Yokohama City University School of Medicine)
}

\begin{abstract}
The efficacy of conventional drugs has been limited in the treatment of xerostoma, lingual pain and abnormal sensations in the throat due to psychosomatic disorders. In addition to these conventional therapies, various Kampo prescriptions have been administered to patients with uncontrollable diseases of the oral cavity, pharynx and larynx. For example, Bakumondo-to and Byakkoka-ninjin-to have been used for the treatment of xerostomia, Oren-to for lingual pain, Saiboku-to for abnormal sensations in the throat. Furthermore, Juzen-taiho-to has also been used in cancer patients to improve their immunological status after the primary curative therapy.

The underlying mechanisms and clinical efficacy of each type of Kampo medicine were analyzed based on the pharmacological actions of each of the herbal components, and we report here our recent clinical experiences. In addition, the use of Kampo for refractory diseases and complaints resistant to conventional treatments is discussed.
\end{abstract}

Key words : diseases of the oral cavity, pharynx and larynx, Kampo medicine, clinical experiences

はじめに

漢方剤は解熱作用をもつ麻黄湯, 痙攣に対する芶薬甘 草湯などの速効性のある薬剤を除けば，比較的慢性疾患 に処方される方剂が多い, 一方, 口腔の乾燥症, 舌痛症, 咽喉頭異常感症などの口腔・咽喉頭疾患に対して奏効性 の高い西洋薬は数少ない(表 1). またこれらの疾患は心 身症の要素も加わり, 症状を複雑化し, 日常診療で苦慮 するところである.こうした慢性疾患に対して西洋薬以 外飞有効な漢方処方を加えることは臨床医として処方の 幅を拡げ，ひいては治療成績の向上飞役立つと考元てい る(表 2). また漢方剤の処方に際しては西洋医学を基盤 に学んだ医師として証などの東洋医学的病性診断(表 3) に拒否的反応を示しやすい，しかし慢性疾患を持つ患者
とは接触期間も長くなり, 必然的に患者の訴光から自然 に証が判明し, 治療に反映できる.

今回は日常でよく見かける口腔・咽喉頭疾患に繁用さ れている漢方剤について構成生薬から見た作用機序，ま た最近の報告と自験例の臨床効果について検討した。

\section{結果と考察}

1. 口腔疾患

A. 口腔乾燥症

従来西洋薬としては, 含嗽, 吸入, 人工唾液などが処 方されてきた。一方, 漢方剤としては麦門冬湯, 白虎加 人参湯を用いている. 
表 1 口腔・咽喉頭分野に扣ける一般処方と漢方処方

· 口腔咽頭乾燥症
·舌痛症
- 口内炎 (再発性アフタ)
- 味覚障害(口苦)
- 咽喉頭炎, 扁桃炎
·咽喉頭異常感症
- 嗄 声
·頭頸部腫瘍(術後, 抗癌剤併用)

含嗽，ステロイド軟膏，マイナートランキライザー, 人工监液

含嗽, ステロイド軟高, マイナートランキライザー 含嗽，ステロイド軟高

vitamin 剂

抗生剤, 消炎鎮痛剤

マイナートランキライザー，消炎酵素剤，（Fe 投与）

喉頭ネブライザー, LMS

BRM 剂
麦門冬湯, 白虎加人参湯

黄連湯

半夏瀉心湯，六君子湯，黄連湯 小柴胡湯 小柴胡湯加桔梗石高 半夏厚朴湯, 加味逍遙散, 柴朴湯, 香蘇散 半夏厚朴湯, 麦門冬湯 十全大補湯, 補中益気湯
表 2 現代医療に扣ける漢方診療の意義

原因の判らない疾患や明らかな病態の見出せないもの 病因や病態は判っていても治療法の確立していないもの 病変が多部位にわたり, 愁訴の多いもの 副作用などで現代医学の治療法が困難なもの 心と体の異常が絡み合っているもの 西洋薬との併用によって相乗あるいは相加の薬理作用が 期待できるもの

医師の力量の充実 一治療選択数の多さ

\section{（a）構成生薬}

麦門冬湯の構成生薬として麦門冬を主とした滋潤効果 すなわち唾液腺, 分泌腺からの分泌能の充進が作用機序

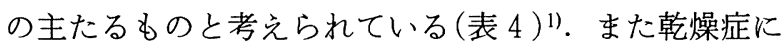
は微細な慢性炎症も続発する。構成生薬である麦門冬， 人参などには免疫賦活作用があり，抗炎症作用として働 くことも奏効する機序の 1 つとして考えられる. 一方， 白虎加人参湯の主成分である石膏には止渴作用があり2),

表 3 漢方診断に打ける体力病性診断

口渴，のぼせ感，熱感，顔面紅潮 粘椆分泌物 (痰, 鼻汁)

筋骨薄弱型 なで肩 胸板薄い

胃腸虚弱

下痢軟便傾向

$$
\text { 熱証 }
$$

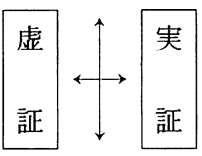

$$
\text { 寒 証 }
$$

冷兄症, 悪寒, 顔面蒼白 (枯燥) 水様分泌物 (痰, 鼻汁)

\begin{tabular}{|c|c|c|c|c|c|c|}
\hline & & 鎮咳作用 & 去痰作用 & 抗炎症作用 & 止渴作用 & 滋潤効果 \\
\hline 麦 門 & 冬 & 0 & 0 & 0 & & 0 \\
\hline 半 & 夏 & 0 & 0 & 0 & & \\
\hline 人 & 参 & & & 0 & & 0 \\
\hline 大 & 菓 & & & & & 0 \\
\hline 粳 & 米 & & & & 0 & 0 \\
\hline 甘 & 草 & 0 & & 0 & & 0 \\
\hline
\end{tabular}

表 4 麦門冬湯の構成生薬と作用

半夏に唾液分泌元進, 抗潰瘍, 免疫賦活作用 全体を通じて粘膜を滋潤し，体液を調節して分泌を增す。 効能・効果：痰の切れにくい咳，気管支炎，気管支ぜんそく

また粳米の滋潤作用さらに人参, 甘草の抗炎症作用と共 合して臨床効果をあらわすものと考光られる(表 5 ).

(b) 臨床効果

麦門冬湯の最近の臨床報告としては，多数例で検討し
壮健闘士型 いかり肩 胸板厚い 胃腸機能丈夫 便秘傾向 
表 5 白虎加人参湯の構成生薬と作用

\begin{tabular}{|c|c|c|c|c|c|}
\hline & & 止渴作用 & 解熱 作 用 & 抗炎症作用 & 血糖降下作用 \\
\hline 石 & 高 & 0 & 0 & & \\
\hline 知 & 母 & 0 & 0 & 0 & 0 \\
\hline 甘 & 草 & & & 0 & \\
\hline 人 & 参 & & & 0 & 0 \\
\hline 粳 & 米 & 0 & & & \\
\hline
\end{tabular}

熱感があり，体液が欠乏し，激しい口渴を目標として用いる.

効能・効果：のどの渴きとほてりのあるもの

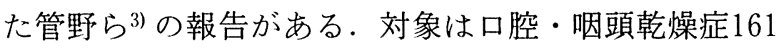
例, 放射線性口腔乾燥症 56 例, 慢性咽喉炎 22 例, シェ グレン症候群 7 例などの258例(男性113例，女性145例）

である. 麦門冬湯 1 回 $9.0 \mathrm{~g}$ を分 3 にて 4 週間投与した. 口腔のカラカラ感, ネバリ感, 飲水切望感, 口腔内疼痛 などの自覚症状の改善度は，著明改善，改善以上が $30 \%$ 以上で(図 1)，やや改善を含めるとこれらの症状の $60 \%$ 以上に有効性が観察されている. 全般改善度, 患者の印 象度は，やや改善，少し良くなった以上を効果のあった 症例と考兄ると75\%前後となる(図 2 )。しかし放射線性， シェーグレン症候群の乾燥症の効果はそれぞれ30\%, 14
全般改善度 $(n=258)$ : やや改善以上

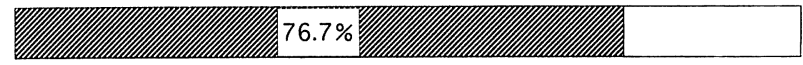

患者の印象 $(n=257)$ : 少し良くなった以上

$75.9 \%$

図 2 口腔乾燥症に対する麦門冬湯の効果 (管野澄雄, 他 : 19953) より改変)

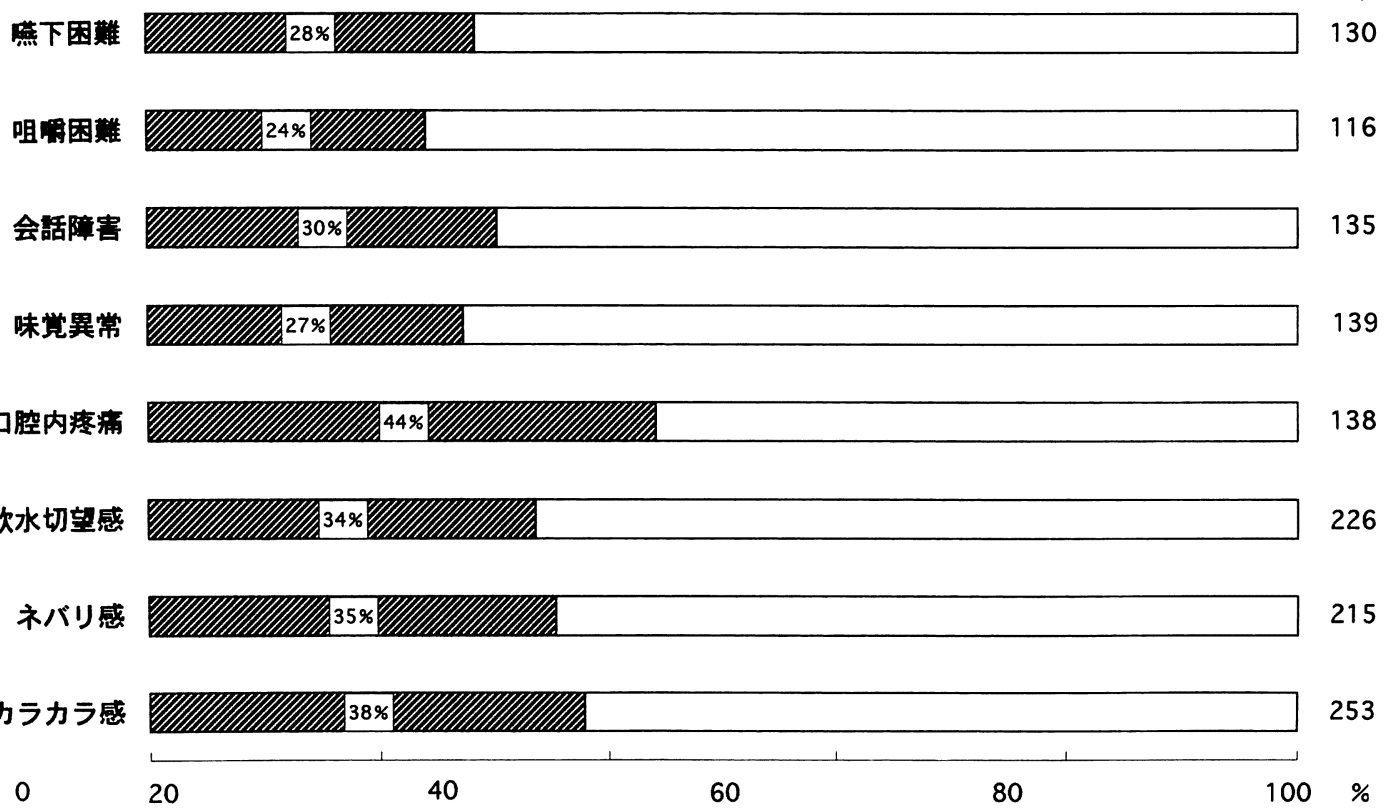

図 1 自覚症状別改善度 (改善以上)

(管野澄雄, 他：19953) より改变） 
\%と低く，これらの唾液腺そのものが萎縮した疾患には この薬剤の効果が劣ることが判る. 効果発現時期は, 投 与後 2 週目で奏効例の $70 \%$ 以上に見られ，4 週間の投与 終了時には奏効した全例に効果が認められている(図 3 ). 逆に 4 週間の投薬で無効の症例では麦門冬湯の効 果が劣ることを示していると思われる. われわれも放射 線性あるいはシェーグレン症候群による口腔乾燥症を除 く19症例に麦門冬湯を単独投与し自覚的に 13 例(68\%)に 有効例を観察している. これらの症例の効果発現時期も $2 \sim 6$ 週目であった.

一方，白虎加人参湯に関しても高龄者を対象に(平均 年齢78歳) $9.0 \mathrm{~g} /$ 日, 分 3 で投与した山内 ${ }^{2)}$ は自覚症状 の改善は投与 8 週後までに認め, 奏効率は高齢者が対象 にもかかわらず $50 \%$ 以上と報告している.

現在のところ, 口腔乾燥症には麦門冬湯, あるいは白 虎加人参湯に吸入, 含嗽 (ポピヨンヨードは乾燥感を強 くするため, アズレンなど)を加えて 4 〜 週経過を観 察し，この期間に心因性要素が強いと思われる症例には 加味逍遥散あるいは柴朴湯あるいはマイナートランキラ イザーを加え経過を観察している.

\section{B. 舌痛症}

この疾患も西洋薬では苦慮する疾患である. 舌にアフ 夕性口内炎のあるものはステロイド軟高，含嗽などで軽 快する場合もあるが，こうした明らかな病変がなく舌痛 症を訴える症例が多い。そこで黄連湯 $7.5 \mathrm{~g} /$ 日を分 3 で舌痛症 32 例に 8 週間単独投与し，その奏効性を見た4).
舌痛症の症例を観察すると, 乾燥症からくる舌乾燥, そ れに引き続く微細舌炎, さらに心身症的な強い症状の訴 えがある.そこでこうした症状に効果が期待できる黄連 湯を選択した．今回の症例では既治療として23例に含濑 剤, 13例にステロイド塗布剤, 6 例に鎮痛剤, 5 例にマ イナートランキライザーが使用されていた．この32例で は神野ら5)の虚実判定スコアを参考に, 虚証, 実証に分 別したが, 虚証が21例, 虚実中間が11例で実証の症例は なかった(表 6 ).

(a) 構成生薬

黄連湯の薬理作用としては人参, 半夏などの唾液分泌 六進作用, 大霜, 甘草, 桂皮などの鎮静作用, またもと もと抗消化性潰瘍作用をもち胃炎に働く黄連には粘膜修 復作用がある。さらに人参が入ることによって免疫賦活 作用による抗炎症作用も期待できる(表 7 )。こうした黄 連湯の構成生薬の相乗作用によって舌痛症に効果がある と考えた。

(b) 臨床応用

発症から来院までの期間は 6 力月上 1 年以内が 15 例 と最も多く，1 年以上舌痛症で悩んでいる症例も10例あ った(表 8 ). 性別では女性が25例と $80 \%$ 近くを占め,な かでも50歳代の女性に多かった（表 9). 前述したように， この年㱓層の女性に多いことはこの疾患が心身症の要因 を多分に含むことを示唆しているように思われる．投与 後自覚症状を参考にした著効と有効例が26例あり奏効率 は $81 \%$ であった．本人の自覚症状に口腔内乾燥症のある

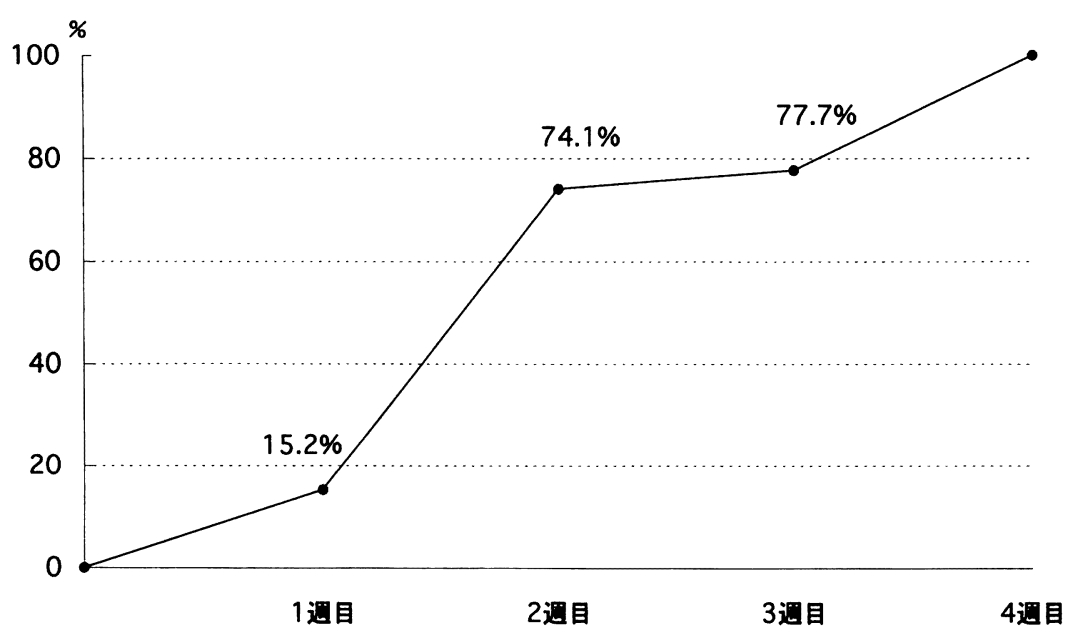

図 3 口腔乾燥症に対する麦門冬湯の効果発現時期 $(n=197)$

(管野澄雄, 他 : 1995 3 上り改变) 
表 6 神野ら ${ }^{5)}$ の虚実判定実証スコア

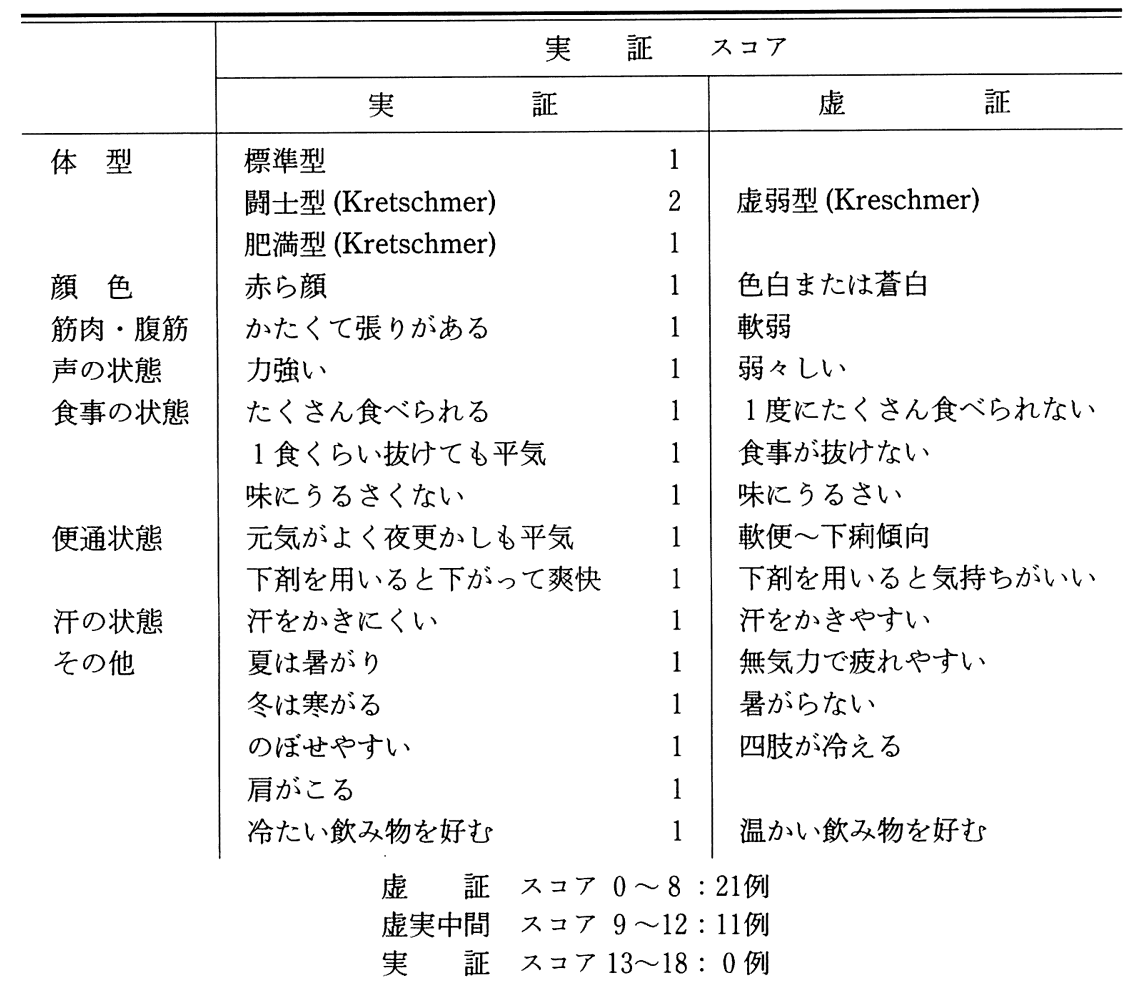

表 7 黄連湯の構成生薬と作用

\begin{tabular}{|c|c|c|c|c|c|}
\hline & & 唾液分泌元進作用 & 抗炎症作用 & 鎮 静 作 用 & 抗潰瘍作用 \\
\hline 半 & 夏 & 0 & 0 & 0 & 0 \\
\hline 黄 & 連 & 0 & 0 & & 0 \\
\hline 甘 & 草 & & 0 & 0 & 0 \\
\hline 桂 & 皮 & & 0 & 0 & 0 \\
\hline 大 & 棵 & & & 0 & 0 \\
\hline 人 & 参 & 0 & 0 & & 0 \\
\hline 乾 & 姜 & & & 0 & 0 \\
\hline
\end{tabular}

胃部の停滞感があり, 舌に黄色苔, 舌苔がある場合に用いる.

効能・効果 : 急性胃炎, 口内炎, 二日酔

表 8 発症から来院までの期間

\begin{tabular}{c|c}
\hline \hline 来院までの期間 & 症例数 \\
\hline 3 カ月未満 & 1 \\
$3 \sim 6$ カ & 6 \\
6 カ月〜 1 年 & 15 \\
$1 \sim 5$ 年 & 8 \\
5 年以上 & 2
\end{tabular}

症例と無い症例に分けて有効率を検討したが，とくに差 は観察されなかった(表10).ついで黄連湯投与から奏効 までの期間を検討したが, 著効例では 4 週目までに半数 以上に効果が認められるものの, 有効例では奏効までの 期間がやや長い傾向が観察された(表11).

ちなみに 8 週間投与で効果の無かった 6 症例に対して は, 3 例に加味逍遥散を加え, 2 例に柴朴湯を, 1 例に 
表 9 症例の性と年齢

\begin{tabular}{c|c|c}
\hline \hline & 男 & 女 \\
\hline 40 歳 & 1 & 4 \\
$50 \sim$ & 3 & 13 \\
$60 \sim$ & 3 & 5 \\
$70 \sim$ & 0 & 2 \\
$80 \sim$ & 0 & 1 \\
\hline 計 & 7 & 25
\end{tabular}

表10 口腔内乾燥症の有無と有効性

\begin{tabular}{|c|c|c|c|}
\hline & 著 効 & 有 効 & 不 変 \\
\hline $\begin{array}{c}\text { 口曌内乾燥症 } \\
\text { 有 }(18 \text { 例) }\end{array}$ & 5 & 9 & 4 \\
\hline $\begin{array}{c}\text { 口攻内乾燥症 } \\
\text { 無 }(14 \text { 例) }\end{array}$ & 4 & 8 & 2 \\
\hline
\end{tabular}

マイナートランキライザーを加えて経過を観察し，いず れの症例も小康状態を保っている．現在さらに前述した 漢方剂，マイナートランキライザーとの併用に加え，含 嗽，ステロイド塗布剤，自宅での吸入療法を加味して舌 痛症の症例に対応している。

2. 咽 - 喉頭疾患

A. 急性咽頭炎, 扁桃炎

この疾患に対しては抗生剂，抗菌剂，消炎鎮痛剤，消 炎酵素剤, 含嗽, トローチなどを西洋薬として用いてい
表11 有効性と奏効までの期間

著効：自覚的に全くあるいはほとんど消失 有効：自覚的に軽快

\begin{tabular}{c|c|c}
\hline 奏効までの期間 & 著 効性 & 有 \\
\hline$\sim 2$ 効 \\
$\sim 4$ 週 & 1 & 0 \\
$\sim 6$ 週 & 4 & 5 \\
$\sim 8$ 週 & 3 & 7 \\
\hline 計 & $9(28 \%)$ & 5 \\
\hline
\end{tabular}

る.われわれの施設でも小柴胡湯加桔梗石膏を抗生剂と ともに消炎鎮痛剤のかわりに用いているが，この方剤の 単独使用は軽度の炎症疾患に対してのみである。そこで 中等症までの急性咽頭炎, 扁桃炎に対して小柴胡湯加桔 梗石膏 $(7.5 \mathrm{~g} /$ 日, 分 3$)$ を単独で 4 週間用いた泰地ら ${ }^{6)}$ の成績をもとに解説をすすめる.

(a ) 構成生薬

もともとこの漢方剤は小柴胡湯に桔梗, 石膏を加え, 抗炎症作用を強めたものである. 柴胡の抗炎症作用に石 膏, 桔梗の解熱作用が加わり，炎症に奏効すると考兄ら れる(表12).

(b ) 臨床応用

中等症までの急性咽頭炎, 扁桃炎に対する小柴胡湯加 桔梗石膏単独投与のこの報告によると，自覚症状ではこ れらの疾患に特有な自発痛, 嬹下痛に対して, 著明改善,

表12 小柴胡湯加桔梗石高の構成生薬と作用

\begin{tabular}{|c|c|c|c|c|c|c|}
\hline & & 抗炎症作用 & 抗アレルギー作用 & 解熱 作 用 & 鎮咳·去痰作用 & 鎮痛・鎮痙作用 \\
\hline 石 & 膏 & & & 0 & & \\
\hline 柴 & 胡 & 0 & 0 & 0 & & \\
\hline 半 & 夏 & 0 & & & & 0 \\
\hline 黄 & 芩 & 0 & 0 & & & 0 \\
\hline 桔 & 梗 & 0 & & 0 & 0 & 0 \\
\hline 大 & 來 & & 0 & & & \\
\hline 人 & 参 & 0 & & & & 0 \\
\hline 甘 & 草 & 0 & 0 & & 0 & 0 \\
\hline 生 & 姜 & 0 & & 0 & 0 & 0 \\
\hline
\end{tabular}

小柴胡湯に桔梗と石膏を加え，抗炎症作用を強めたもの.

効能・効果 : 扁桃炎, 扁桃周囲炎 
改善が70\%前後, 発熱, 頭痛に対して $90 \%$ 以上の改善度 が得られまた他覚症状でも腫脹, 発赤, 膿栓などには 80 $\%$ 近くの著明改善, 改善が認められている(図 4 ). 効果 発現までの日数をみると，服用 3 日目で $50 \%$ 以上，4 日 目で $80 \%$ に効果が観察され，この漢方剂が速効性である ことが判る(図 5 ). 前述したように現在われわれの施設 でも, 扁桃炎を含む咽頭炎の軽症例にはこの薬剤単独, また中等症以上には抗生剤や抗菌剤との併用や，さらに 腫脹, 発熱, 疼痛などの症状が極めて強い症例にはさら に消炎鎮痛剂を加えている。

B. 咽喉頭異常感症

この疾患も心身症的要素があり, 症例が増加傾向にあ る. 炎症, 腫瘍など器質的病変のある症例では, その病 变に対する治療が行われているが，器質的病変のない症
例には治療に苦慮することが多い。西洋薬としては alprazolam, ethyl loflazepate などのマイナートランキ ライザーを用いることが多い，一方，漢方剂として繁用 されているのは柴朴湯である。

(a ) 構成生薬

この漢方剤は小柴胡湯と半夏厚朴湯との合剤で, 柴胡 に代表される抗炎症作用と半夏，厚朴を中心とする鎮静， 抗ストレス作用を合わせもつ(表13).すなおち微小な咽 喉頭の慢性炎症を持つ症例に対しても，不安神経症から くる咽喉頭異常感症に対しても薬効があるものと推察さ れる。

(b) 臨床応用

平成 3 年 8 月〜 4 年 7 月の 1 年間に当院に咽喉頭異常 感症で来院した症例は男86例，女102例の計188例であっ

\section{自覚症状別改善度}

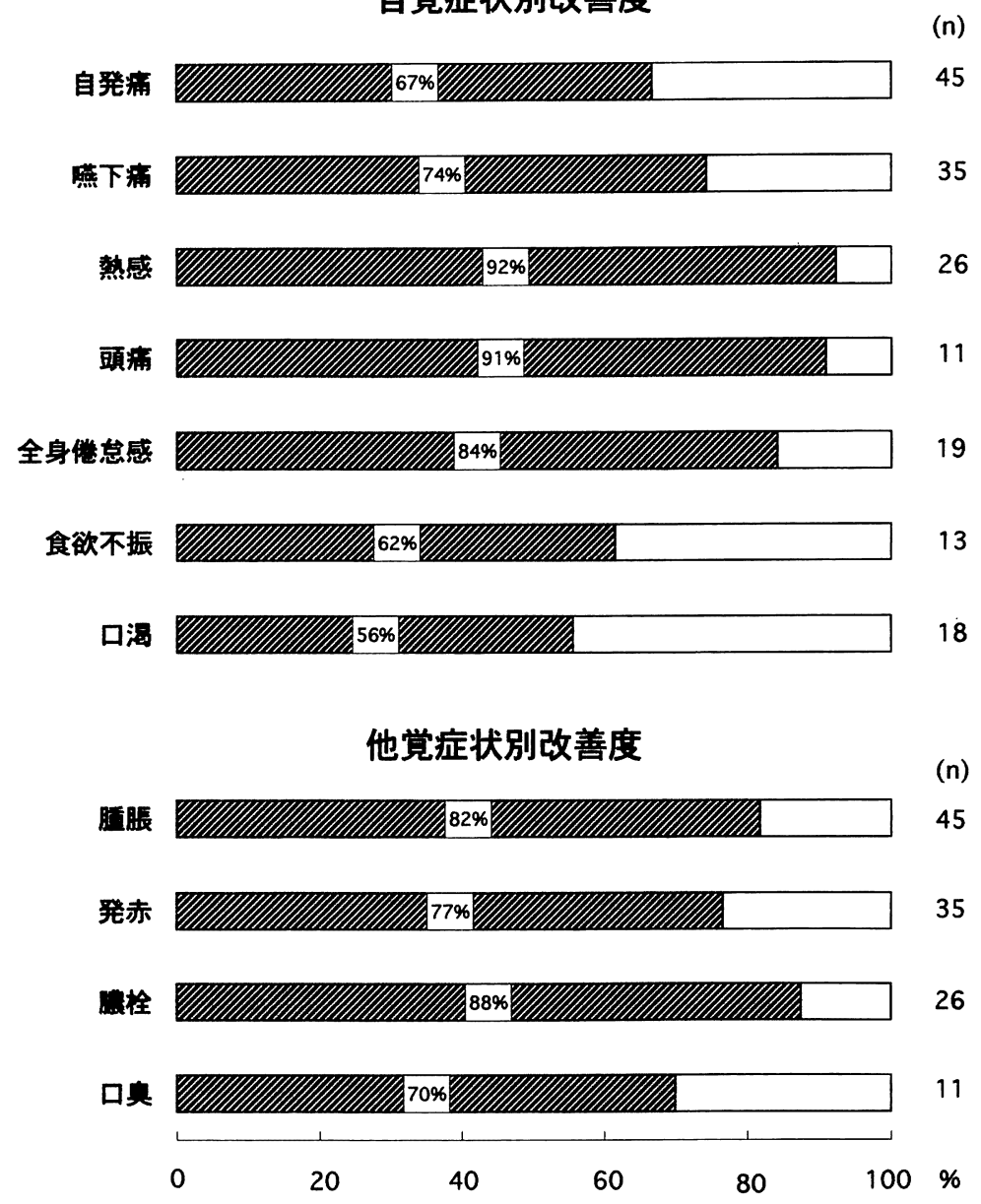

図 4 小柴胡湯加桔梗石膏の咽頭炎, 扁桃炎に対する効果(改善以上) (泰地秀信, 他 : 19936) ょり改変) 


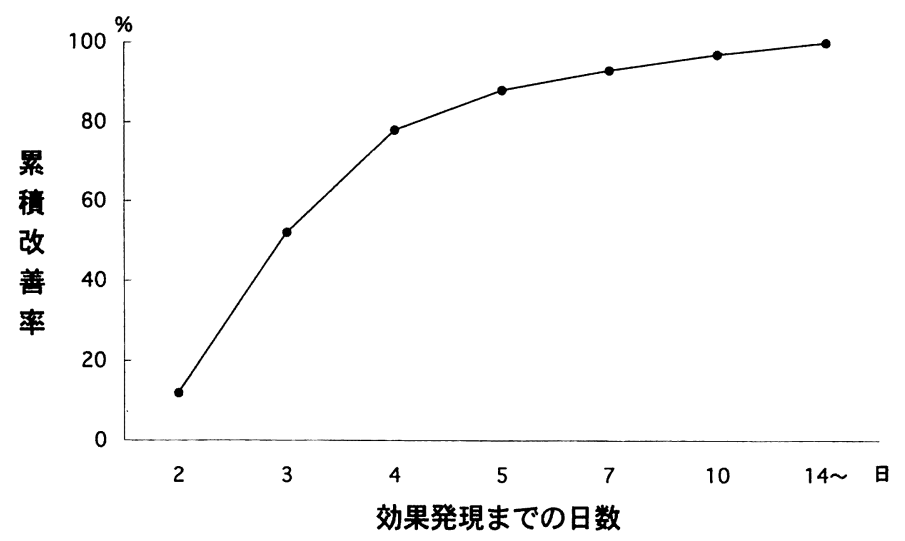

図 5 咽頭炎, 扁桃炎に対する小柴胡湯加桔梗石膏の効果発現日数 (泰地秀信, 他 : 19936) より改変)

表13 柴朴湯の構成生薬と作用

\begin{tabular}{|c|c|c|c|c|c|c|c|}
\hline & & 抗炎症作用 & 鎮痛 作 用 & 鎮静 作用 & 抗ストレス作用 & 中权抑制 & 抗潰瘍作用 \\
\hline 柴 & 胡 & 0 & & 0 & 0 & 0 & \\
\hline 半 & 夏 & 0 & 0 & 0 & & 0 & \\
\hline 黄 & 芩 & 0 & 0 & & & & \\
\hline 人 & 参 & 0 & 0 & & 0 & 0 & \\
\hline 甘 & 草 & 0 & & 0 & & & 0 \\
\hline 生 & 姜 & 0 & 0 & & & 0 & \\
\hline 获 & 苓 & & & 0 & & & 0 \\
\hline 大 & 東 & & & 0 & 0 & & 0 \\
\hline 厚 & 朴 & 0 & & 0 & 0 & & 0 \\
\hline 蘇 & 葉 & & & & & & \\
\hline
\end{tabular}

主に呼吸器の炎症症状や, 精神不安があり, 咽頭に異物感がある場合に用いる

効能・効果 : 気管支ぜんそく，気管支炎，不安神経症

た(平均年齢51.1歳)7). 症状はつまった感じ, 痛み感, 異物感，ひっかかり感等が多く（図 6 )，来院までの期間 は 1 週間から 2 年以上と幅広い期間にわたっていた（図 7 ). 甲状腺疾患やその他の咽喉頭の器質的疾患が $5 \%$ あったが(図 8 ), 明らかな鼻・副鼻腔, 咽喉頭の炎症を 除いた所見的に異常のない症例が $40 \%$ 以上あり，188例 中, 103例の咽喉頭異常感症に薬剤内服による保存的治 療を施行した。漢方剤は柴朴湯 $(7.5 \mathrm{~g} /$ 日，分 3 )を，マ イナートランキライザーは ethyl loflazepate を 4 週処方 し，患者の自覚的症状の推移を参考に奏効性を検討した. 柴朴湯が処方された症例の有効以上の奏効率は $50 \%$ 以上
であった。一方, 柴朴湯単独と柴朴湯とマイナートラン キライザーの併用での奏効性を比較すると，有効以上の 奏効率には差がないものの併用例の方が著効率が高い傾 向にあり，この疾患が心身症的性格をもつことが推察さ れた。

咽喉頭異常感症に対する柴朴湯の報告は多いが8) 11), 荻野ら ${ }^{10)}$ は柴朴湯の投与 2 週間と 4 週間後で効果を比 較し， 2 週間で無効の症例は 4 週間投与を継続しても有 効以上になることは少なく，2 週間で効果判定した投与 法を推奖している。一方山際 ${ }^{11)}$ は 2 週間投与し，他の 消炎酵素剤，マイナートランキライザーと比較して柴朴 
男 性

(例)

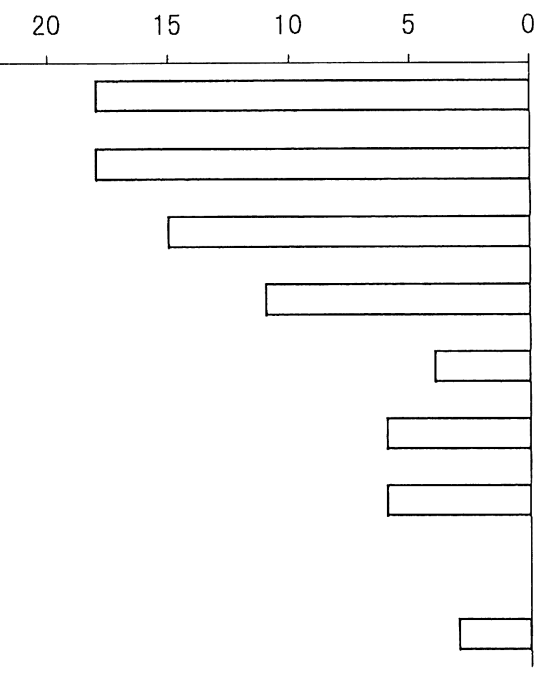

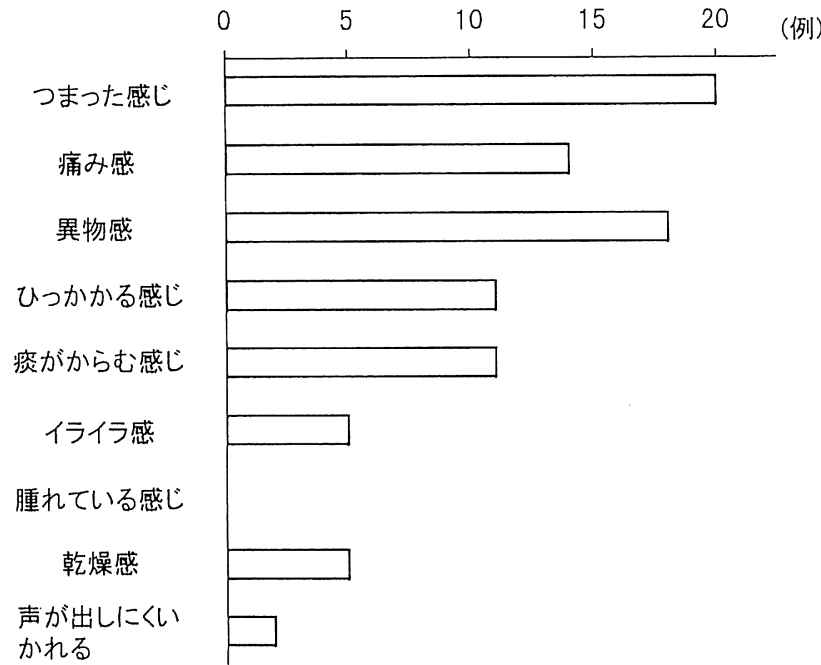

図 6 咽喉頭異常感の内容
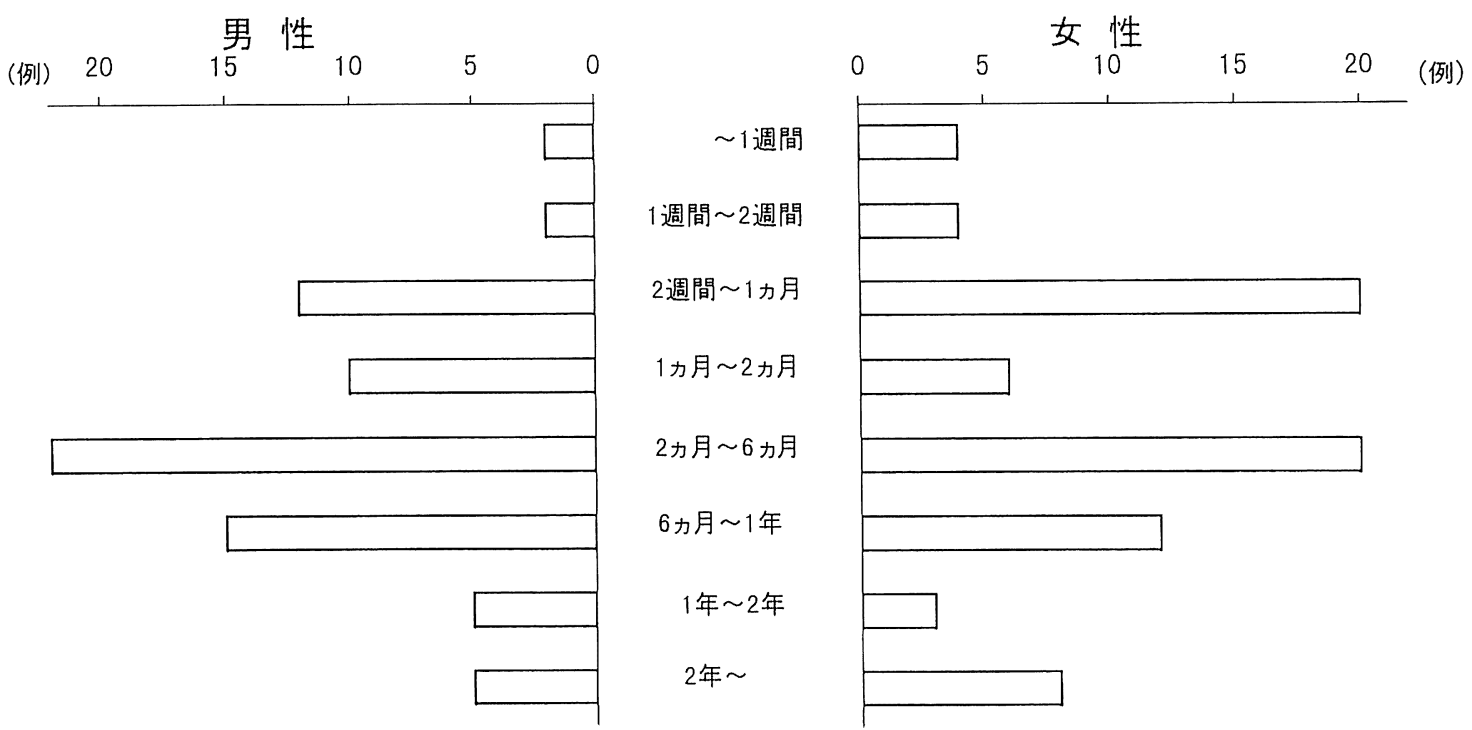

図 7 咽喉頭異常感出現から当科受診までの期間

湯の効果は投与終了後も持続する特徵を述べている.

これらの結果をふま克, 胃・食道を含む上部消化管に 器質的なあるいは明らかな咽喉頭の炎症所見のない症例 に対してはまず柴朴湯を処方している。一般的には 4 週 間で軽快しない症例で乾燥症等の軽度の慢性炎症が疑わ れ，心身症的訴えのない症例には含嗽，消炎酵素剤ある いは麦門冬湯と自宅での吸入療法を加兄る。一方 40,50
歳代の女性で心身症的訴兄の多い症例には柴朴湯に加味 逍遥散あるいはマイナートランキライザーを加它経過を 観察している。一方，男性の症例に対しては柴朴湯とマ イナートランキライザーの併用を試みている．現在こう した併用療法によって $80 \%$ 近い奏効性を認めている.

\section{3 ．悪性腫瘍}

頭頸部腫瘍は扁平上皮癌が多く, 中でも咽頭癌は進行 
男 性
女 性

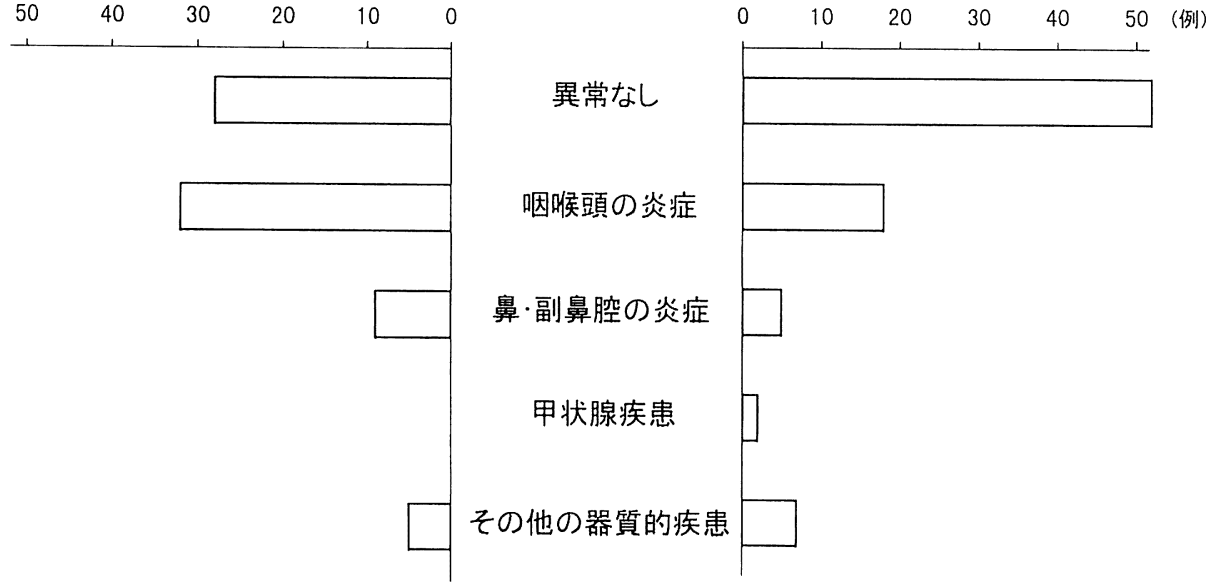

図 8 咽喉頭異常感患者に認められた所見

平成 3 年 8 月～平成 4 年 7 月

男 86例, 女 102例 計 188例

平均年秢 51.1 歳
癌が多く予後が悪い. 現在頭頸部癌に対して免疫賦活剂 として保険適用のあるのは溶連菌製剤 OK-432 のみであ る.

漢方剤とくに人参，柴胡には免疫賦活作用があること が判明している ${ }^{12)}$. われわれの健常人七ト末梢血単核球 を用いた検討では，人参が柴胡よりも強いDNA 合成能
を示した(図 9 )。注射剤である OK-432 の外来投与では 免疫賦活作用がパルス様の一過性であるため ${ }^{13)}$, OK432 投与間の免疫能維持に十全大補湯, 補中益気湯など を加えている.

十全大補湯の構成生薬を示すが(表14)，十全大補湯は 四物湯と四君子湯の合剂に黄者と桂皮を加えた10種の構

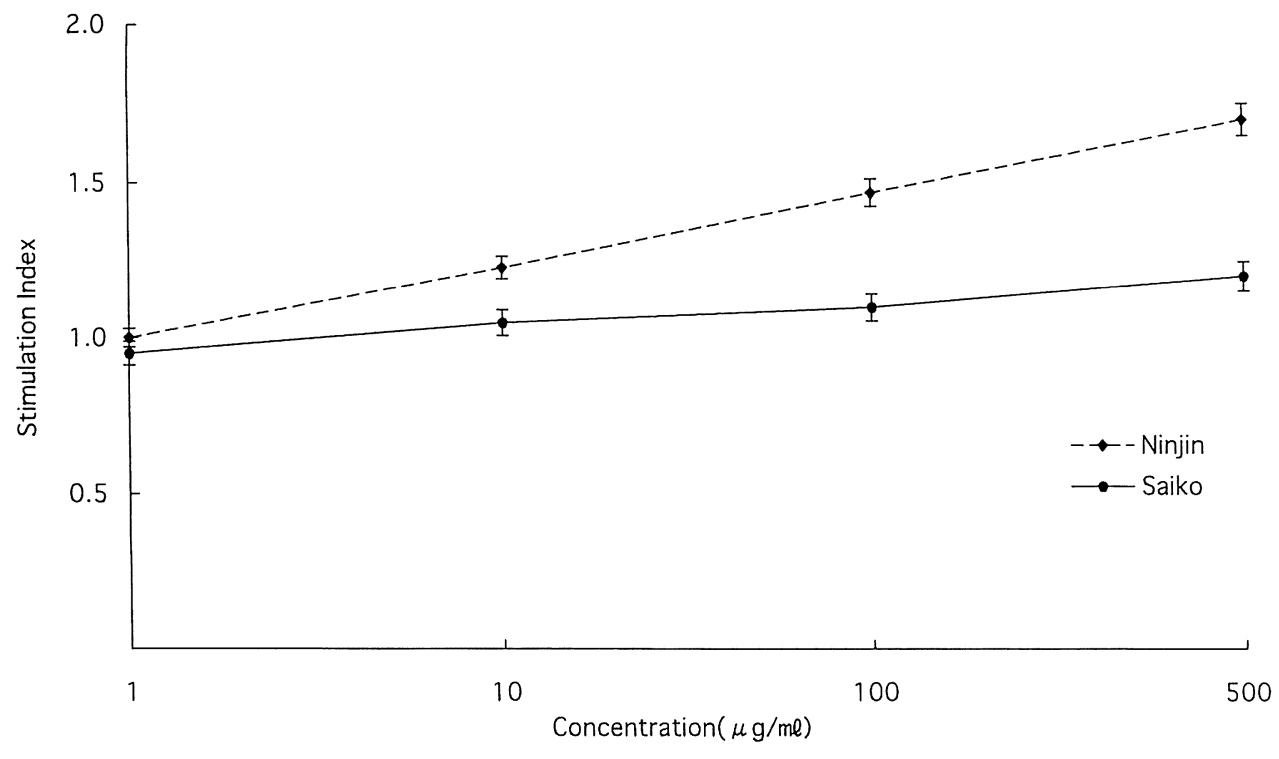

図 9 柴胡, 人参によるヒト末梢血単核球 DNA 合成への影響 
表14 十全大補湯の構成生薬と作用

\begin{tabular}{|c|c|c|c|c|}
\hline & & 血液循環改善 & 消化機能改善 & 免疫調節作用 \\
\hline 当 & 帰 & 0 & & 0 \\
\hline 苟 & 薬 & 0 & & 0 \\
\hline 川 & 芎 & 0 & & 0 \\
\hline 地 & 黄 & 0 & & 0 \\
\hline 人 & 参 & & 0 & 0 \\
\hline 蒼 & 术 & & 0 & 0 \\
\hline 获 & 苓 & & 0 & 0 \\
\hline 甘 & 草 & & 0 & 0 \\
\hline 黄 & 耆 & 0 & & 0 \\
\hline 桂 & 皮 & & 0 & \\
\hline
\end{tabular}

四物湯 (貧血, 末梢循環改善) に四君子湯 (消化機能改善)を合わせ, 黄者と 桂皮を加えたもの.

気虚 (消化器機能低下し, 精神的・肉体的活動力が低下) と血虚(貧血)の両 方を改善.

効能. 効果 : 病後の体力低下, 疲労倦怠, 食欲不振, 貧血, 手足の冷兄

表15 漢方薬に拈ける副作用

\begin{tabular}{|c|c|c|c|c|c|c|c|c|}
\hline & $\begin{array}{l}\text { 偽アルドス } \\
\text { テロソ症 }\end{array}$ & ミオパシー & 過敏症 & 消化器 & 間質性肺炎 & 肝 臟 & 泌尿器 & その 他 \\
\hline \multicolumn{9}{|l|}{ 麦門冬湯 } \\
\hline \multicolumn{9}{|l|}{ 白虎加人参湯 } \\
\hline \multicolumn{9}{|l|}{ 黄連湯 } \\
\hline \multicolumn{9}{|l|}{ 六君子湯 } \\
\hline \multicolumn{9}{|l|}{ 小柴胡湯 } \\
\hline \multicolumn{9}{|l|}{ 柴朴湯 } \\
\hline \multicolumn{9}{|l|}{ 小柴胡湯加桔梗石膏 } \\
\hline \multicolumn{9}{|l|}{ 加味逍遥散 } \\
\hline \multicolumn{9}{|l|}{ 香蘇散 } \\
\hline \multicolumn{9}{|l|}{ 十全大補湯 } \\
\hline \multicolumn{9}{|l|}{ 補中益気湯 } \\
\hline 牛車腎気丸 & & & - & 0 & & & & 心悸え進, のぼせ \\
\hline \multicolumn{9}{|l|}{ 半夏白术天麻湯 } \\
\hline \multicolumn{9}{|l|}{ 柴苓湯 } \\
\hline \multicolumn{9}{|l|}{ 辛夷清肺湯 } \\
\hline 小青竜湯 & 0 & 0 & ○ & 0 & & & & 不眠, 頻脈等 \\
\hline
\end{tabular}

・過敏症…発疹, 搔痒など・消化器…胃部不快感, 食欲不振など

・肝臓…GOT, GPT の上昇・泌尿器…膀脱炎様症状 
成生薬から成る，人参，黄耆をはじめとして多くの構成 生薬が免疫調節作用を持っている. 微妙な構成生薬の違 いはあるものの補中益気湯は十全大補湯の構成生薬のう ち地黄を除き，柴胡が加味されている。十全大補湯でむ かつき等の消化器症状を示す症例は地黄による副作用と 考えられるため，地黄を含まない補中益気湯に变更して いる.

頭頸部癌患者の一次治療後に十全大補湯 $7.5 \mathrm{~g} /$ 日, 分 3 で投与し、リンパ球サブセットで免疫能を測定した が，治療前に比較して $\mathrm{CD} 4 / 8$ 比の上昇傾向，リンパ球 幼若化率の上昇を認めたが有意差を観察するまでにはい たらず，兔疫賦活作用をもつ漢方剤の有用性については 今後の検討課題といえる.この免疫能の充進した症例で は十全大補湯投与によって全例に食欲六進作用が認めら れていた。

小柴胡湯は内科領域で $\mathrm{B}$ 型, $\mathrm{C}$ 型肝炎患者に繁用され ている．頭頸部癌患者で 5-Fluouracil の大量持続投与に よって薬物性肝炎を生じた症例には小柴胡湯 $7.5 \mathrm{~g} /$ 日 を処方し，良好な結果を得ている。

\section{4. 副作用}

最近漢方剤の副作用が宣伝されている．しかし漢方剤 も生体に薬物として投与されることから，当然のことな がら副作用はあることを理解しておく必要がある(表 15）。前述した漢方剤の中で比較的副作用を経験するの は甘草を含む方剤である．とくに甘草を含む方剤同士を 併用すると低カリウム血症による軽度のミオパシーが出 現する．また黄芩，地黄を含む方剤はむかつきなどの消 化器症状を呈する。しかし柴胡を含む方剤は耳鼻咽喉科 領域では長期に処方することが少ないせいか筆者自身は 経験していない。

\section{まとめ}

以上漢方剂の口腔・咽喉頭疾患に対する臨床応用を述 べてきた。まだまだ漢方剤については不明な点が多く(表 16), 薬剤の薬理作用から疾患への適応を求める西洋医 学を学んできた臨床医にとって漢方剤の処方に躊躇する 医師も多いと思われる。しかし，漢方鼡には西洋薬で効 果のない疾患に対して奏効を示す方剤もあり，治療手段 を豊富に持つことは臨床医にとって不可欠ではないかと 考えている.
表16 漢方治療の問題点

1. 有効性の確認：症例の病態の違い $\rightarrow$ 奏効に差

2. 薬理作用の解明 : 一つの生薬に多成分, 合剂として の相乗作用

3 . 西洋薬との併用による有用性の証明

4. 処方の一定化

5. 副作用の解明：多剂併用での重複生薬

\section{参考文献}

1 ) 山際幹和 : 口腔乾燥症に対する漢方治療 3 . 耳鼻咽喉科 外来でみる口渴, 口乾患者の治療経験. Prog Med 13： 2379〜2383, 1993.

2 ）山内康平：口腔乾燥症に対する漢方治療 2. 高路者の唾 液分泌動態と口腔乾燥症. Prog Med 13 : 2364 2378, 1993 .

3 ) 管野澄雄, 田沢 卓, 竹山 勇, 他: 口腔咽頭乾燥症への ツムラ麦門冬湯の効果. 耳鼻臨床 $88 ： 961 〜 966,1995$.

4 ）佃守, 河野英浩, 澤木修二, 他 : 器質的病変のない舌 痛症に対する黄連等の治療成績. Prog Med 15:1491〜 1495, 1995

5 ) 神野卓三, 霜島 進 : 口腔乾燥症に対する漢方薬の効果 ーシェーグレン症候群について一.漢方医学 $17: 173 \sim 177$, 1993.

6 ）泰地秀信，鈴木理文：扁桃炎，咽頭炎に対する小柴胡湯加 桔梗石膏 (TJ109) の効果. Prog Med 13 : 1692 1698, 1993.

7 ) 三上康和，佃守，持松いづみ，他：咽喉頭異常感症の 臨床的観察. 日気食会報 $44: 273 \sim 277,1993$.

8 ）山際幹和, 原田輝彦, 坂倉康夫 : 柴朴湯を用いた咽喉頭異 常感症の治療.耳鼻臨床 $84: 837 \sim 851,1991$.

9 ) 谷野 徹, 武田八重子, 原田克也, 他 : 咽喉頭異常感症に 対するッムラ柴朴湯の使用経験. Prog Med 11:3111 3114,1994

10）荻野 乞：咽喉頭異常感症に対する柴朴湯の治療効果. 日 本漢方治療シンポジウム講演内容集. 36〜 43頁，メディカ ルトリビューン, 東京, 1994

11）山際幹和：咽喉頭異常感症に対する柴朴湯の臨床効果. 日 本漢方治療シンポジウム講演内容集. 44 47頁, メディカ ルトリビューン, 東京, 1994

12）内田温士 : BRM としての漢方剂の作用とその可能性. Prog Med $15:$ 125 128, 1995.

13）佃 守, 古川 嵫, 吉田豊一, 他 : 細胞障害活性からみ た OK432 至適投与間隔の検討. 癌と化学療法 16:423〜 $425,1989$. 